by purely chemical means. Fourteen years later, he found a similar reaction with lead tetrafluoride.

Fascinated with Mendeléeff's system, Brauner entered into scientific correspondence with the genial Russian chemist in 1881 and was greatly impressed by meeting him in St. Petersburg. There a cordial friendship between the two enthusiastic Slavonic chemists began, to last for twenty-five years, until the death of Mendeléeff.

A problem which occupied Brauner's mind for a long time was the position of the rare earth elements in the Periodic System. As a strong adherent of the tabular form of the system, he expected that these elements would somehow fit in so as to show their chemical analogies. By determining carefully their atomic weights, he was already able to predict the gap between neodymium and samarium. In his investigations at Manchester, Brauner succeeded in showing the complexity of didymium, denoting by Dix and Di $\beta$ what Auer von Welsbach three years later called praseodymium and neodymium. This brilliant work was submitted by Brauner to the Charles University of Prague for his 'habilitation' thesis. He was appointed assistant professor there in 1890 and full professor in 1897.

During his whole academic career, Prof. Brauner worked intensively at the chemistry of the rare earths and on the determination of atomic weights. As a specialist in the first branch, he was asked by Mendeléeff to write the account on rare earths in his famous textbook "Principles of Chemistry", whilst in the other branch he immortalised himself in Abegg's well-known "Handbuch der anorganischen Chemie", to which he contributed his masterly critical discussion on atomic weights. As an authority on these determinations, he fought, together with Venable, for the new base $\mathrm{O}=16 \cdot 000$, right down to its general adoption at the Paris Congress in 1900.

Prof. Brauner retired in 1925, after forty-three years of teaching, during which time he lectured to generations of chemists and pharmacists. The highest scientific distinctions came to him not only from his own people, but still more so from abroad. Those he treasured most were the honorary memberships of the Chemical Society of London, the American Chemical Society and the Société Chimique de France, and the honorary D.Sc. of the University of Manchester. His seventieth birthday was celebrated by a jubilee number of the Recueil des Travaux Chimiques des Pays-Bas in 1925, and his seventyfifth birthday by the jubilee number of the Collection of Czechoslovak Chemical Communications in 1930.

The personality of Prof. Brauner was one of imposing and original individuality. His Herculean figure, quick penetrating eyes, high and broad forehead, and strong features harmonised well with his commanding voice, dry remarks and sarcastic wit. Yet his sanguine enthusiasm often also brought tears into his eyes, revealing his gentleness of heart and love for mankind and the whole of Nature. One of his great hobbies was astronomy, the progress of which he followed as eagerly as that of chemistry. No wonder that with such naturalistic bent he soon became a passionate and ardent reader of NATURE, of which he had read carefully every number, starting from his Manchester days in 1882. Often he contributed to it thoughtful and conscientious reports. His recreation was sport, which he introduced and promoted enthusiastically in Bohemia, having become attached to it during his studies in England. His Spartan mode of life most probably preserved his health in spite of the noxious atmosphere of the chemical laboratory and his somewhat delicate lungs. Yet pneumonia, which attacked him several times in his stronger days, succeoded at last in overcoming him in his eightieth year, to the sincere regret of his two sons and daughter and his many devoted friends and pupils.

J. H.

\section{Sir Leslie Mackenzie}

WE regret to record the death of Sir William Leslie Mackenzie, which occurred in Edinburgh on February 28.

Sir Leslie Mackenzie was a native of Ross-shire and graduated M.A., with double honours, at the University of Aberdeen in 1882. He studied medicine in Aberdeen and Edinburgh and, at the latter University, took the degree of M.B., C.M., with honours, in 1888, and M.D., with highest honours, in 1895. He held the D.P.H. and was a fellow of the Royal College of Physicians of Edinburgh. In addition to achieving a brilliant career in medicine, Sir Leslie was a recognised authority on psychology and mental philosophy. $\mathrm{He}$ had gained the Fullerton and Ferguson scholarships in mental philosophy, and was at one time examiner in mental philosophy as well as in medical jurisprudence and public health at the University of Aberdeen. His later work was recognised in the award of the Medal of Honour of the University of Brussels in 1920. In Aberdeen also he was a resident medical officer in the Royal Infirmary and afterwards was assistant professor of physiology and Arnott lecturer in physiology at Gordons Colleges. In his earlier work he had thus a wide knowledge and interest, as well as considerable and diverse experience.

For Sir Leslie's later work, which was more of a public nature and had its outcome in the develop. ment of the various modern branches of public health service during his term of office on the Local Government Board and Scottish Board of Health, he had his first insight while, for a time, assistant to that eminent and widely-known hygienist, Prof. Matthew Hay, medical officer of health for the City of Aber. deen. From this assistantship he became the first medical officer of health for the combined counties of Wigtown and Kirkcudbright, under the Local Government (Scotland) Act, 1889, where he had to organise the public health work of a very large area. $\mathrm{He}$ and Prof. Hay were selected to give evidence before the Royal Commission (for Scotland) on physical training. He had carried out for the Commission and reported on the examination of six hundred school children, and the Commission's report resulted in the establishment of the School Medical Service.

In 1894, Sir Leslie was appointed medical officer 
of health for Leith, where his ability and achievements, added to those already accomplished in his previous appointments, led to his selection, in 1901, for the post of medical inspector under the Local Government Board for Scotland. In 1904, he became medical member of the Local Government Board and later of the Scottish Board of Health which took its place. In the latter capacities he took a prominent part in the development of the tuberculosis service and the scheme for medical services in the Highlands and Islands of Scotland. His name is also closely associated with the development of the maternity and child welfare service, he having, in 1915, prepared a report for the Carnegie Trust on "Scottish Mothers and Children", published in 1917. At this time also he was a member of the Royal Commission on Housing, the Ballantyne Commission, a branch of public health work which he himself regarded as among the most important, if not the most important, of his activities for the betterment of the people of Scotland. He was also crown nominee for Scotland on the General Medical Council.

Among Sir Leslie's published writings, other than those already referred to, were "The Nervous System" in Prof. Bain's "Senses and Intellect"; "The Development and Outlook of Public Health" in Nelson's Loose Leaf Medicine; "Health and Disease" ; "The Health of the School Child" ; "The Medical Inspection of School Children".

The sympathy of all who knew him, personally or by repute, will go out to Lady Mackenzie, who also is a well-known and active social worker. Lady Mackenzie has taken a keen interest and no small part in the effort for the improvement of conditions in Scotland, and is a member of several boards of public bodies and of the Departmental Committee now receiving evidence on the health services of Scotland.

\section{News and Views}

\section{'Backward Tribes' in the India Bill}

Col. WedGwood, by moving two amendments on Clause 91 of the India Bill in the House of Commons on March 22, secured from Sir Samuel Hoare a statement of the intentions of the Government in dealing with the primitive tribes of India. He pointed out the extreme undesirability of the probable course of action of the Provincial Governments in an effort to assimilate tribal areas to conditions in the rest of the territory under their jurisdiction, and urged the retention of such areas under British control with a system of administration similar to that of indirect rule' which has been introduced in West Africa. That the problem is by no means negligible in its dimensions is indicated by the numbers affected. Col. Wedgwood's estimate puts the numbers of the backward tribes at 43,000,000, of whom 13,000,000 only will be affected by the protective measures proposed by the Government. These figures are in excess of those given in the Census Report of 1931, where the primitive tribes are stated to number $25,000,000$ (in round numbers), of whom $8,280,000$ are said to retain their tribal religion. The difference is probably due to the more rigid exclusion in the Census figures of tribes which have passed over recently, or are in process of passing, into the depressed classes, the usual fate of tribes which have come into contact with outside conditions.

Arc observers are agreed as to the delicate equilibrium of the social organisation of the primitive tribes of India, which is unable to withstand even the most impartial application of the principles of British justice. In Rajputana, for example, it has been found to have led, in the desire to distribute even-handed treatment, by almost imperceptible degrees to an increase in the power of the land-owner and the restriction of the rights of the tribal holding. Any increase in facilities of communication has had a rapidly disintegrating effect. Sir Samuel Hoare was able to give the House an assurance that the Government has this aspect of the matter in view; and he informed the members that, as the result of consultation with expert opinion in India, it had been decided that certain areas, wherever such treatment was possible, would be scheduled for control by the Governor only. $\mathrm{He}$ closed with the confident statement that "the Government had made the position safe". In so doing, he appeared to rely to a great extent upon the fact that there has developed a school of Indian administrators "who had specially concentrated on the study of the kind of problem that was in the mind of Col. Wedgwood". Some assurance, however, that measures are being taken to ensure that the supply of such administrators will not fail in the changed conditions would have been even more welcome.

\section{Antiquities in Iraq}

Further details of the allocation of antiquities from Ur as between the Bagdad Museum and the institutions which were responsible for the Joint Expedition are given by Dr. Leonard Woolley in Antiquity of March. These, unfortunately, had to be omitted from his communication in The Times (see Nature, 134, 999; 1934); but they should convince any impartial judge of the fairness of Dr. Woolley's contention that the principle of division has operated in favour of the Bagdad Museum, and that there is no ground for the accusation that Iraq has received a negligible proportion of the finds or has been deprived of priceless treasures which should not have left the country. Dr. Woolley admits that in the earlier years of the excavations objects of exceptional importance or value were allotted to the share of the Expedition; but this was due to the fact that the Bagdad Museum had not then the technical equipment necessary for their special treatment and preservation. As Dr. Woolley's statement is precise, its detail is open to verification; but a reply which 